\title{
A representação alegórica do Estado em Debret e Pedro Américo
}

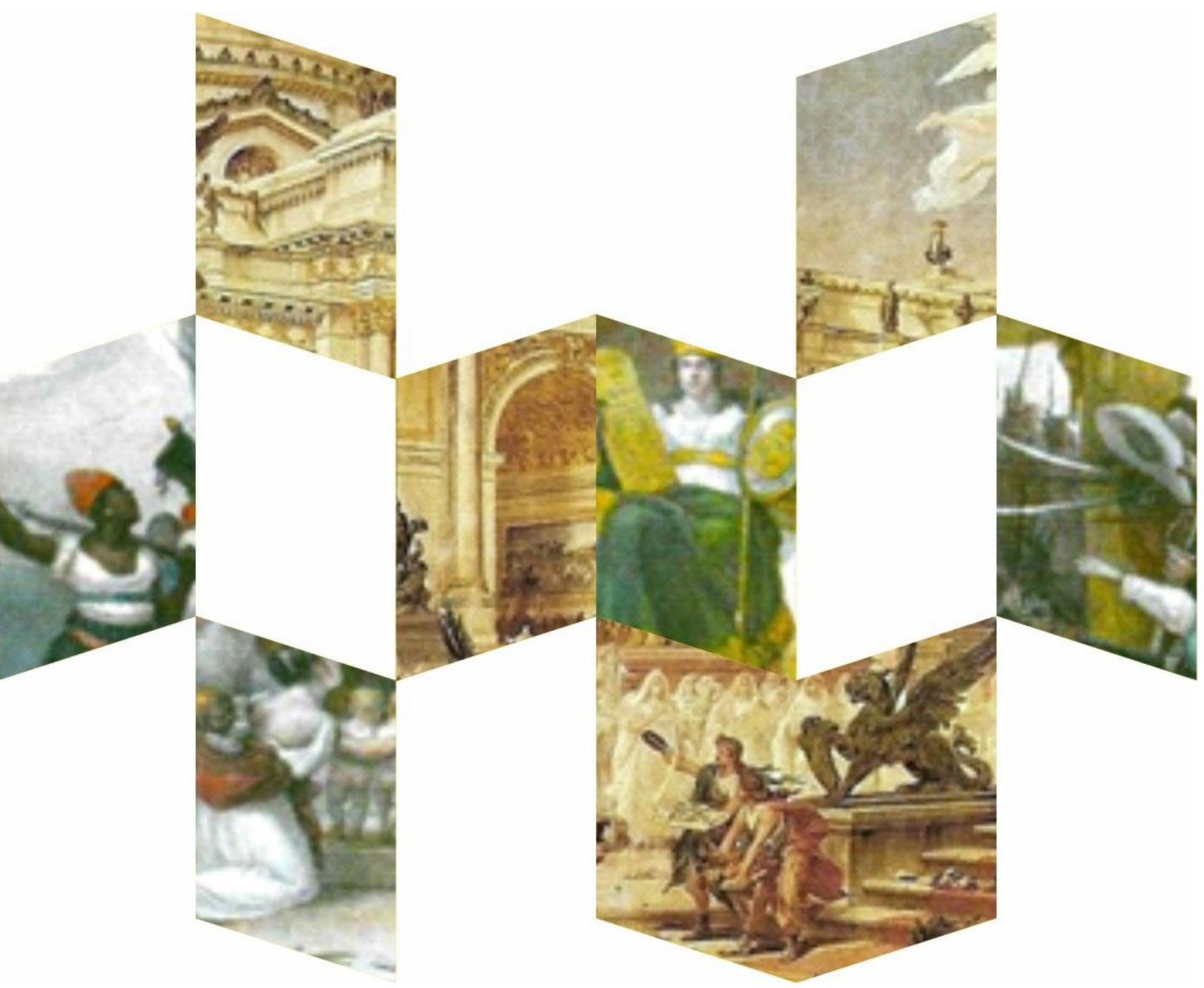

Pano de boca para noite de gala no teatro da corte por ocasião do coroamento de D. Pedro I. JeanBaptiste Debret, 1822, litografia, e Paz e concórdia. Pedro Américo, 1902, óleo sobre tela, 300 × $431 \mathrm{~cm}$,

\section{Guilherme Frazão Conduru}

Doutor em Artes Visuais pela Universidade Federal do Rio de Janeiro (UFRJ). Autor do livro O Museu Histórico e Diplomático do Itamaraty: história e revitalização. Brasília: Funag, 2013. gfconduru@gmail.com 


\section{A representação alegórica do Estado em Debret e Pedro Américo}

The allegorical representation of the State in Debret and Pedro Américo

\section{Guilherme Frazão Conduru}

\section{RESUMO}

O artigo propõe uma análise iconológica comparada de duas pinturas alegóricas dedicadas à representação do Estado, realizadas em diferentes momentos de busca de consolidação de uma nova ordem política, após rupturas institucionais: o pano de boca para o teatro da corte do Rio de Janeiro na noite de gala da coroação de Pedro I, de Jean-Baptiste Debret, de 1822; e Paz e concórdia, de Pedro Américo, alegoria-exaltação esboçada em 1895 e vendida ao Ministério das Relações Exteriores em 1903, depois de tentativa de exposição no salão parisiense de 1900. Enquanto a obra de Debret procurou representar elementos que seriam característicos do Estado brasileiro, inclusive a diversidade étnica, a tela de Pedro Américo, como alegoriacoringa, representou conceitos universais e conteúdo nacional adaptável.

PALAVRAS-CHAVE: arte no Brasil (séculos XIX e XX); pintura alegórica; representação do Estado.

\begin{abstract}
The article proposes a compared iconological analysis of two allegorical paintings dedicated to the representation of the state, both produced during the consolidation of new political orders after institutional ruptures: the stage curtain for the coronation gala in honour of Pedro I in Rio de Janeiro court theatre(1822), by JeanBaptiste Debret; and Paz e concórdia (1902), by Pedro Américo, exaltation allegory, sketched in 1895 and sold to the Ministry of Foreign Relations in 1903, after an attempt to be exposed in the Paris salon of 1900. While Debret's work attempts to represent characteristic elements of the Brazilian state, including its ethnical diversity, Pedro Américo's canvas, as a joker allegory, represents universal concepts and adaptable national contents.
\end{abstract}

KEYWORDS: Art in Brazil (XIX and XX centuries); allegorical painting; State representation.

Momentos de reconfiguração do sistema político - seja por meio de rupturas institucionais mais ou menos violentas, seja por meio de acomodações de interesses de grupos sociais - tendem a tornar mais explícitos os vínculos entre a arte e a representação do estado e da nação. No Brasil, a Independência, em 1822, e a República, em 1889, ensejaram demandas oficiais por referenciais de identidade e os detentores do poder político solicitaram aos artistas a produção de símbolos para representar a comunidade que se desejava nacional.

Este texto pretende oferecer uma análise iconológica comparada de duas obras que tiveram como objetivo representar o Estado após momentos de ruptura política: o pano de boca de Jean-Baptiste Debret (1768-1848), de 
1822, realizado para o teatro da corte na noite de gala que se seguiu à coroação de Pedro I (1798-1834), e a tela Paz e concórdia, de Pedro Américo (1843-1905), de 1902, vendida pelo artista para o Ministério das Relações Exteriores (MRE), em 1903.

\section{A legitimação da Independência na alegoria do Império: o pano de boca de Debret}

A Revolução liberal do Porto de 1820 provocou a convocação das Cortes Gerais de Portugal com o objetivo de promulgar uma constituição. Um dos efeitos do movimento foi a suspensão da censura, o que provocou uma proliferação de periódicos no Brasil, nos quais se reproduziam textos liberais de autores europeus e norte-americanos e se discutiam conceitos como "constituição", "representação" e "deputados". Desencadeava-se um processo de formação de uma nova cultura política. Ao mesmo tempo, a frequência aos espetáculos no Teatro São João criava uma nova sociabilidade, que alimentava a incipiente formação de uma opinião pública na corte do Rio de Janeiro. Assim, a obra cenográfica de Debret viria dar-se a ver num momento de constituição de um espaço público de socialização e debate na imprensa e no teatro. ${ }^{1}$

Após o rompimento com Lisboa, a necessidade de institucionalizar o novo arranjo político implicava a construção de um consenso, que estabelecesse laços de solidariedade entre as elites das antigas capitanias e garantisse o reconhecimento da nova ordem pela população. Para construir esse consenso seriam necessários investimentos sobre o imaginário coletivo, ressignificação de símbolos antigos, criação de novos rituais cerimoniais e invenção de novos referenciais de identidade.

De acordo com a tradição portuguesa, a legitimação de um novo soberano implicava a aclamação popular, que consistia na apresentação do soberano ao povo e, ao mesmo tempo, na aceitação pelo povo desse novo soberano. Um grupo liberal, defensor da convocação de uma assembleia constituinte, aproximou-se do príncipe e pretendeu associar ao sentido tradicional da aclamação o significado de expressão da soberania popular. Em 12 de outubro de 1822, aniversário de Pedro, foi organizada a cerimônia de sua aclamação como defensor perpétuo e imperador constitucional do Brasil, que poderia significar a subordinação do imperador à vontade popular.

Na visão de um grupo conservador, a cerimônia de coroação e sagração de Pedro I se prestaria a contrabalançar a dimensão democrática da aclamação. A nova cerimônia, simultaneamente política e religiosa, adquiria, assim, um sentido conservador e complementar à aclamação ao reforçar a imagem de Pedro I como herói fundador do Império e da nação brasileira.

As duas cerimônias expressavam as duas fontes do poder do imperador: o princípio do governo representativo, baseado no constitucionalismo e na vontade popular, e o princípio da legitimidade dinástica, com base no direito divino.

\footnotetext{
${ }^{1}$ Ver LEEHARDT, Jacques. Un regard décalé sur la construction de la nation brésilienne. In: DEBRET, JeanBaptiste. Voyage pittoresque et historique au Brésil. S./1.: Imprimerie Nationale, 2014, p. IX-XXXIII.
} 
Nessa conjuntura, Debret foi encarregado de realizar o pano de boca a ser inaugurado na noite de gala do dia da coroação, 1o de dezembro. A obra aparece como gravura em Viagem pitoresca e histórica, sob o título Rideau d'avant-scène exécuté au théâtre de la cour, pour la représentation d'apparat à l'occasion du Couronnement de l'Empereur D. Pedro 1er (Pano de boca executado para o teatro da corte para a representação de gala por ocasião da coroação do imperador d. Pedro I), seguida de texto descritivo. ${ }^{2}$

Na condição de cenógrafo contratado pelo teatro, Debret já realizara, em 1818, um cenário para bailado histórico em homenagem a João VI (17671826), que acabava de ser aclamado, e ao casamento do príncipe herdeiro. Embora tenha o mesmo objeto que o pano de boca - a representação alegórica do poder político -, esse cenário representa um monarca do Ancien régime, cujo poder era exercido em caráter absoluto, enquanto o pano de boca representa uma autoridade legitimada por um contrato social, a constituição.

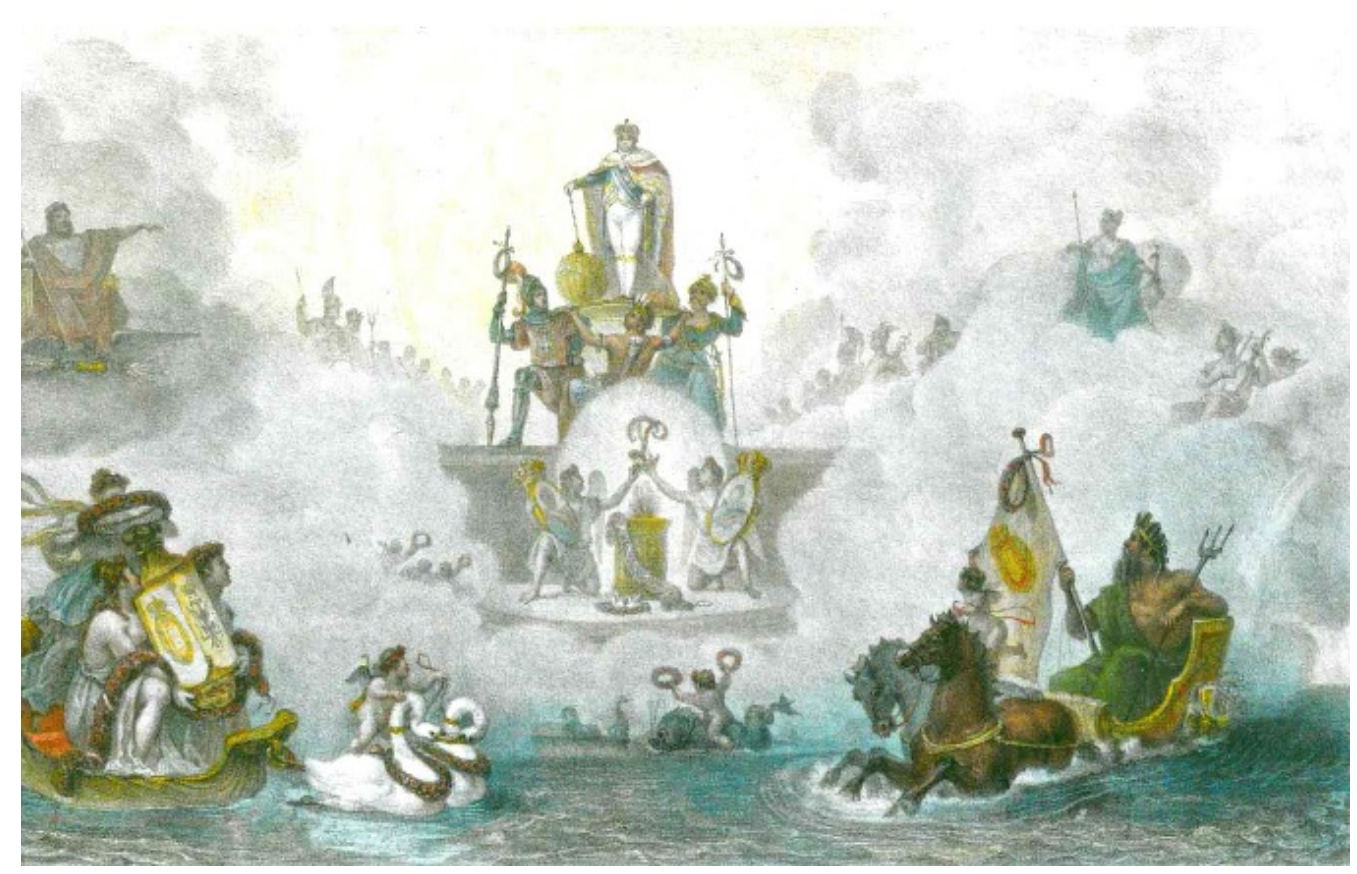

Figura 1. Cenário para bailado histórico. Jean-Baptiste Debret, 1818, litografia.

Sem preocupação realista, o cenário foi realizado "em transparente", técnica na qual a pintura é realizada sobre uma superfície transparente iluminada por trás, o que permitia manipulações de iluminação que simulavam animação sobre a cena representada. ${ }^{3}$ Em linha com o princípio da legitimidade dinástica - que justifica o exercício do poder pelo direito divino -, a figura do rei português desponta no Olimpo envergando o traje real, com coroa,

\footnotetext{
2 Ver DEBRET, Jean-Baptiste, op. cit., p 558-560.

3 Os "transparentes", considerados precursores dos panoramas, foram uma invenção de Louis Carrogis Carmontelle (1717-1806), gravador, desenhista e crítico de arte francês. Ver LEEHARDT, Jacques, op. cit., p. XXVII, nota 41.
} 
manto e bastão, atributos tradicionais da autoridade monárquica. Sobre um pavês - grande escudo em cima do qual os reis se faziam desfilar em meio às tropas, segundo costume de origem germânica -, o rei aparece em pé, com a mão esquerda na cintura e, na mão direita, um bastão, que repousa sobre esfera, simbolizando domínio sobre o globo, alusão ao caráter intercontinental do império português. A pose do rei é derivada daquela do famoso retrato de Luís XIV (1638-1715), de 1701, por Hyacinthe Rigaud (1659-1743), também observável no retrato a óleo de João VI realizado por Debret e pertencente ao MNBA. As três figuras que sustentam o escudo são personificações masculinas das três nações que formam o Reino Unido de Portugal, Brasil e Algarves: respectivamente, um soldado trajado à moda medieval, um índio, de costas $\mathrm{e}$ de braços abertos, e uma terceira figura, com turbante, o que remete à moda mourisca. Logo abaixo desse grupo, duas figuras ajoelhadas, o Hímen e o Amor, seguram dois retratos com representações do príncipe herdeiro e de sua esposa austríaca, a indicar a continuidade da dinastia.

Nas nuvens pairam três divindades: Júpiter, que traz uma águia de asas abertas junto aos pés e aponta para o homenageado; Juno, que tem ao lado um pavão, símbolo da imortalidade e da ressureição; e Apolo, que aparece com sua lira. Júpiter, Juno e Apolo simbolizariam, respectivamente, a autoridade, a proteção do Estado e a capacidade criadora. Ao fundo, um grupo de divindades forma um semicírculo atrás do monarca.

No primeiro plano, sobre as águas, Vênus, em concha marinha rebocada por par de cisnes brancos guiado por Cupido, conduz duas Graças, que exibem para o rei uma berlinda coroada com os escudos de armas português e austríaco. No lado oposto, no seu carro puxado por dois cavalos, desponta Netuno, que traz sob o braço esquerdo o tridente e com a mão direita segura o pavilhão do Reino Unido, referência à expansão marítima portuguesa e a seu império colonial.

A alegoria para o cenário do bailado histórico apoia-se na mitologia greco-romana para exaltar João VI, monarca por direito divino; ao contrário do pano de boca, como se verá adiante, o cenário do bailado não faz referência à constituição ou ao povo. Se, por um lado, o estilo do cenário levou Jacques Leehardt a falar num "gosto rococó" e sua encenação celestial sugeriu a Marcela Camargo a possibilidade de que Debret tivesse utilizado como referência obras alegóricas do veneziano Giovanni Battista Tiepolo (1696-1770), também dedicadas à glorificação de casas dinásticas ${ }^{4}$, deve-se, por outro lado, notar que o arranjo do conjunto é simétrico, com as figuras e grupos dispostos de forma equilibrada, o que expressa uma concepção clássica. Seja como for, as energias liberais e anti-absolutistas - desencadeadas na Europa após 1789 e que reverberaram com vigor em Portugal após o movimento constitucionalista de 1820 - obrigariam o monarca português a retornar à sua antiga capital, em 1821, a fim de garantir sua permanência no trono. Apesar de conceitualmente distinto como figuração política, uma vez que representa outro sistema

\footnotetext{
${ }^{4}$ Cf. LEEHARDT, Jacques, op. cit., p. XXVII, e CAMARGO, Marcela Dantas. Jean-Baptiste Debret e o pano e boca de 1822: o lugar da pintura de história no teatro da corte. Dissertação (Mestrado em História da Arte) Unifesp, Guarulhos, 2017.
} 
de exercício do poder, o cenário, de 1818, pode ser considerado um antecedente do pano de boca, de 1822.

Debret inicia o texto que explica o pano de boca caracterizando o momento vivido no final de 1822 como de "admirável de entusiasmo": sentia-se a "energia nacional" dividida entre os preparativos para a suntuosa cerimônia da coroação e para as campanhas militares destinadas a expulsar as tropas portuguesas. O artista comenta a instrução de José Bonifácio (1763-1838), ao ser apresentado ao esboço da obra, de que as palmeiras fossem substituídas por um motivo de arquitetura regular para afastar qualquer associação da sociedade brasileira a um "estado selvagem". Debret substituiu as palmeiras por cariátides, como demonstração de que o novo Império compartilhava dos valores da "civilização". Debret acrescenta que, nas vésperas da noite de gala, o próprio imperador e José Bonifácio visitaram, "incógnitos", o teatro para ver a obra terminada e integrada. ${ }^{5}$ Debret tinha consciência de que sua obra cumpria uma função política como instrumento visual para a legitimação do Império. A "visita surpresa" se justificaria como uma "inspeção" para verificar se o pano de boca se adequaria ao desejado fomento da coesão social em torno da fidelidade ao monarca e, portanto, ao Império. Não constitui exagero considerá-lo como a primeira pintura oficial do Brasil como Estado independente, pintura de história na modalidade alegórica que representava, de um lado, o Estado monárquico constitucional e, de outro, o povo, o território e os frutos da terra. ${ }^{6}$

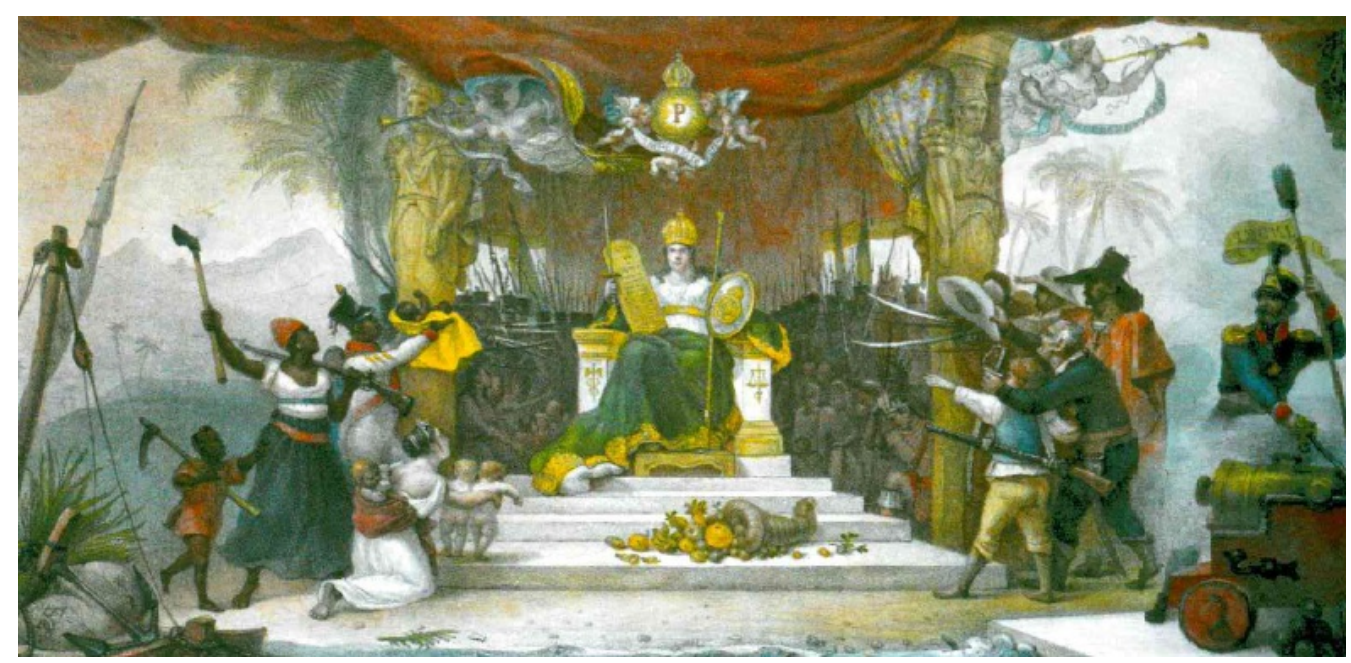

Figura 2. Pano de boca para noite de gala no teatro da corte por ocasião do coroamento de D. Pedro I. Jean-Baptiste Debret, 1822, litografia.

No centro da cena, sentada sobre trono implantado sob uma tenda à beira-mar, a personificação feminina do Império veste uma túnica e ostenta o manto imperial. Com a mão direita empunha espada e com o braço direito apoia a tábua da lei, que representa a constituição. Com a mão e o braço esquerdo leva um escudo com as armas de Pedro I e apoia o cetro imperial. Es-

${ }^{5}$ Cf. DEBRET, Jean-Baptiste, op. cit., p. 559.

${ }^{6}$ Cf. SCHWARCZ, Lilia Moritz. D. Pedro II e seu reino tropical. São Paulo: Claro Enigma, 2009. 
pada e escudo simbolizam a disposição para lutar e defender a independência conquistada; o cetro é o símbolo do poder supremo, atributo de deuses e de monarcas. O trono exibe como ornamentos na parte frontal dos braços os símbolos do Comércio e da Justiça. Aos pés da alegoria principal pacotes de mercadoria aludem ao comércio e à riqueza; no degrau mais baixo da base do trono, cornucópia ostenta os frutos da terra, simbolizando abundância e prosperidade.

No primeiro plano, estreita faixa de areia separa a base do trono do mar, apenas visível na parte inferior da gravura como uma faixa de pequenas ondulações. À esquerda, embarcação com fardos de café e feixes de cana aludem aos produtos da terra e ao comércio. À direita, artilheiro pousa espada sobre um canhão, que acaba de detonar, como a prestar juramento de lealdade ao governo imperial. Esse militar seria uma referência à adesão das forças armadas à nova autoridade política.

No plano de fundo, delineiam-se colinas, palmeiras e o contorno de montanhas. Ocupando o espaço entre o trono e o fundo da tenda, fechado por panejamento, aglomera-se multidão compacta, na qual se distinguem índios guerreiros e soldados que empunham lanças, baionetas e estandartes.

Os grupos de figuras que se posicionam de cada lado da alegoria do Império representam diferentes segmentos da população brasileira, que demonstram adesão à nova soberania. Para transmitir a ideia de coesão social em torno da lealdade ao governo imperial, Debret representa diferentes tipos em posição de prestar juramento, com o braço estendido à frente, elevando o sabre, o chapéu ou exibindo os próprios filhos.

À esquerda do observador, distingue-se uma família de negros que demonstra abnegada dedicação: o pai, de uniforme militar, com os dois braços estendidos, exibe seu filho recém-nascido para a personificação do Império, colocando-o sob sua proteção. A mãe traz apoiada sobre o ombro esquerdo o fuzil do marido e com o braço direito brande machado saudando o Império; outro filho a seu lado, ainda criança, leva ancinho. O machado se destina, segundo Debret, a conquistar a floresta virgem e a defendê-la contra a usurpação. É clara a referência à lealdade, ao trabalho na terra e à disposição para lutar.

A figura de recém-nascido exibido pelo pai ou pela mãe para uma representação da autoridade constitui tipologia iconológica alusiva à lealdade e à proteção, da qual se podem mencionar dois outros exemplos, pelo menos: (I) desenho de Nicolas André Monsiau (1754-1837) intitulado Abolição da escravidão, de 1794, que representa cena de regozijo geral na Convenção por ocasião da aprovação de decreto que estabelecia o fim do trabalho escravo na França e em suas colônias, no qual aparece personagem negro levantando com os dois braços criança na direção dos convencionais, que, em torno de mesa, presidem a reunião7; e (II) pano de boca realizado por Crispim do Amaral (1858-1911), em 1890, para o Teatro da Paz, de Belém, onde mãe indígena faz o mesmo

\footnotetext{
${ }^{7}$ Ver CAMARGO, Marcela Dantas, op. cit., p. 183.
} 
gesto, expondo o filho recém-nascido em direção à alegoria da República brasileira. ${ }^{8}$

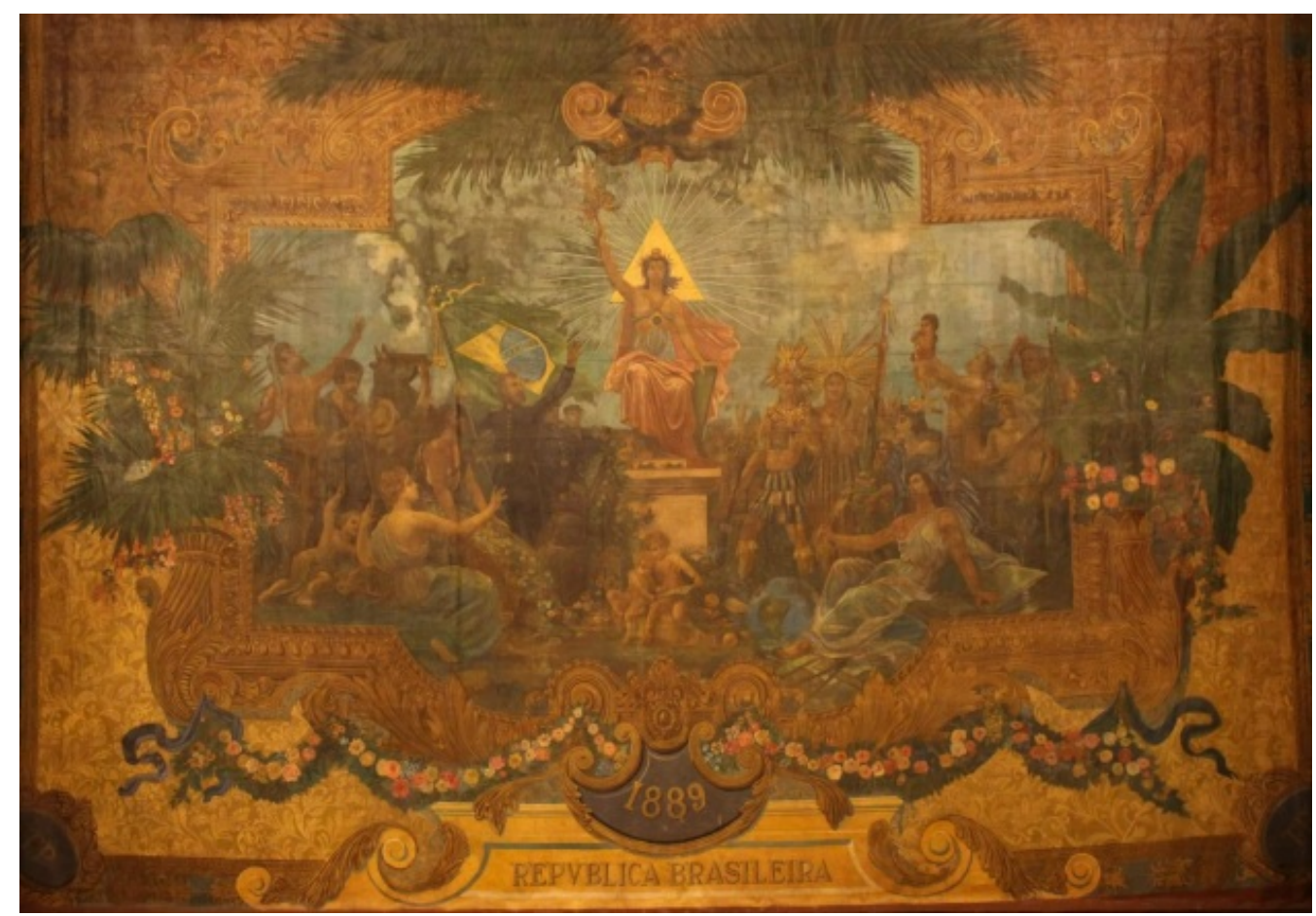

Figura 3. Alegoria da República brasileira. Crispim do Amaral, 1890, óleo sobre tela. Belém, Teatro da Paz, pano de boca.

A mãe negra com o fuzil no ombro e o machado alçado merece comentário específico também pela peça que leva sobre a cabeça: o pileus, cobertura de feltro de base redonda e forma oval, dada ao liberto, na Roma antiga, como símbolo da liberdade adquirida. A versão de origem asiática, o chamado barrete frígio, com uma dobra no topo, tornou-se um dos símbolos mais conhecidos da Revolução Francesa. ${ }^{9}$ Assim, a mãe negra do pano de boca de Debret com o pileus na sua "versão grega", sem a dobra superior, poderia representar, segundo a interpretação de Heloísa Lima, uma liberta negra, armada e pronta para defender sua terra e sua liberdade. Segundo a autora, a figuração dessa mulher negra armada significaria que Debret seria favorável ao fim da escra-

\footnotetext{
${ }^{8}$ Para uma análise iconológica do pano de boca de Crispim do Amaral, ver CORRÊA, Denise Avelino. Alegoria da República: o pano de boca da sala de espetáculos do Theatro da Paz (1890) e a representação da nação paraense republicana. Dissertação (Mestrado em História da Arte) - Unifesp, Guarulhos, 2017.

${ }^{9}$ Ernest Gombrich propõe uma "etimologia dos símbolos" como análise histórica da origem, formação e adaptações de símbolos da linguagem alegórica, que na Revolução Francesa receberam novas camadas de significado. Sobre o bonnetrouge, atributo da liberdade, de grande popularidade no período revolucionário, o autor opina que poderia ter fundido os significados do pileus, do barrete frígio e do barrete vermelho. Cf. GOMBRICH, Ernest. O sonho da razão: o simbolismo da Revolução Francesa. In: Os usos das imagens: estudos sobre a função social da arte e da comunicação visual. Porto Alegre: Bookman, 2012.
} 
vidão. ${ }^{10}$ Seja como for, sabe-se que José Bonifácio concebia a extinção gradual da escravidão como parte um projeto reformista civilizador.

Ao lado da família de negros, jovem mãe ajoelhada - “indígena branca", conforme a expressão usada por Debret - apresenta à alegoria do Império seus dois filhos gêmeos nus, recém-nascidos, ao mesmo tempo em que leva um terceiro às costas, "segundo o costume do país".

À direita do observador, senhor de cabelos brancos saúda a alegoria do Império elevando o chapéu e, com espada na mão esquerda, apresenta seu jovem filho, que traz arma a tiracolo e também saúda a alegoria principal estendo o braço esquerdo. Ao lado, duas figuras masculinas com chapéus de abas largas, uma delas com crucifixo pendurado no peito, representam o povo paulista e o povo mineiro, ambos com espadas alçadas jurando fidelidade ao Império. Em seguida, mais próximo do trono, dois chefes indígenas, com cocar, reclinam-se, ajoelhados, para reverenciar a alegoria.

Na composição de Debret, as poses e a caracterização das figuras e grupos exprimem a ideia de união e de fidelidade do povo à nova autoridade soberana. Debret projetou a desejada integração dos diferentes grupos e etnias formadoras da nacionalidade, inclusive com a assimilação dos indígenas e dos negros, traduzindo em imagem o anseio não realizado de coesão social. Quanto às figuras do paulista e do mineiro, podem ser entendidas como alegorias que representam as províncias em torno das quais o grupo hegemônico construiu a base de um pacto político que se impôs como nacional, representando a união - real ou imaginada - das províncias em torno do governo imperial. ${ }^{11}$

De um lado, é possível enxergar no pano de boca de Debret a afirmação e o reconhecimento simbólicos da autoridade do Estado e, neste sentido, identificá-lo como um antecedente, no que diz respeito ao tema, de Paz e concórdia, de Pedro Américo. De outro, também é possível associar a construção alegórica da união de diferentes segmentos da sociedade brasileira em torno do novo poder soberano ao sentimento agregador evocado pela Primeira missa no Brasil, pintura histórica de Victor Meirelles (1832-1903), de 1860. Assim, o pano de boca de Debret, como primeira representação alegórica do Brasil na condição de Estado soberano e independente, pode ser considerado a matriz das representações do Estado brasileiro.

Nessa linhagem inaugurada por Debret, o pano de boca do Teatro da Paz de Belém do Pará, realizado por Crispim do Amaral, anterior a Paz e concórdia, aproxima-se mais do modelo do que a obra de Pedro Américo, seja pelo suporte ou pela composição estática, centralizada na personificação feminina da República brasileira - sentada, com trajes clássicos, barrete frígio e coroa de louros sobre a cabeça e braço direito levantado, sustentando tocha acesa -, seja ainda pela figuração alegórica de segmentos sociais, como indígenas, caboclos, trabalhadores rurais e militares.

\footnotetext{
${ }^{10}$ Cf. LIMA, Heloísa Pires. Uma Marianne negra no Brasil de Jean Baptiste Debret? 19\&20, v. VIII, n. 2, Rio de Janeiro, jul.-dez. 2013. Disponível em <http://www.dezenovevinte.net/obras/jbd_marianne.htm>. Acesso em 17 set. 2018.

11 Ver LOPEZ, Emilio Carlos Rodriguez. Festas públicas, memória e representação: um estudo sobre manifestações políticas na Corte do Rio de Janeiro (1808-1822). São Paulo: Humanitas/FFLCH/USP, 2004, p. 286.
} 


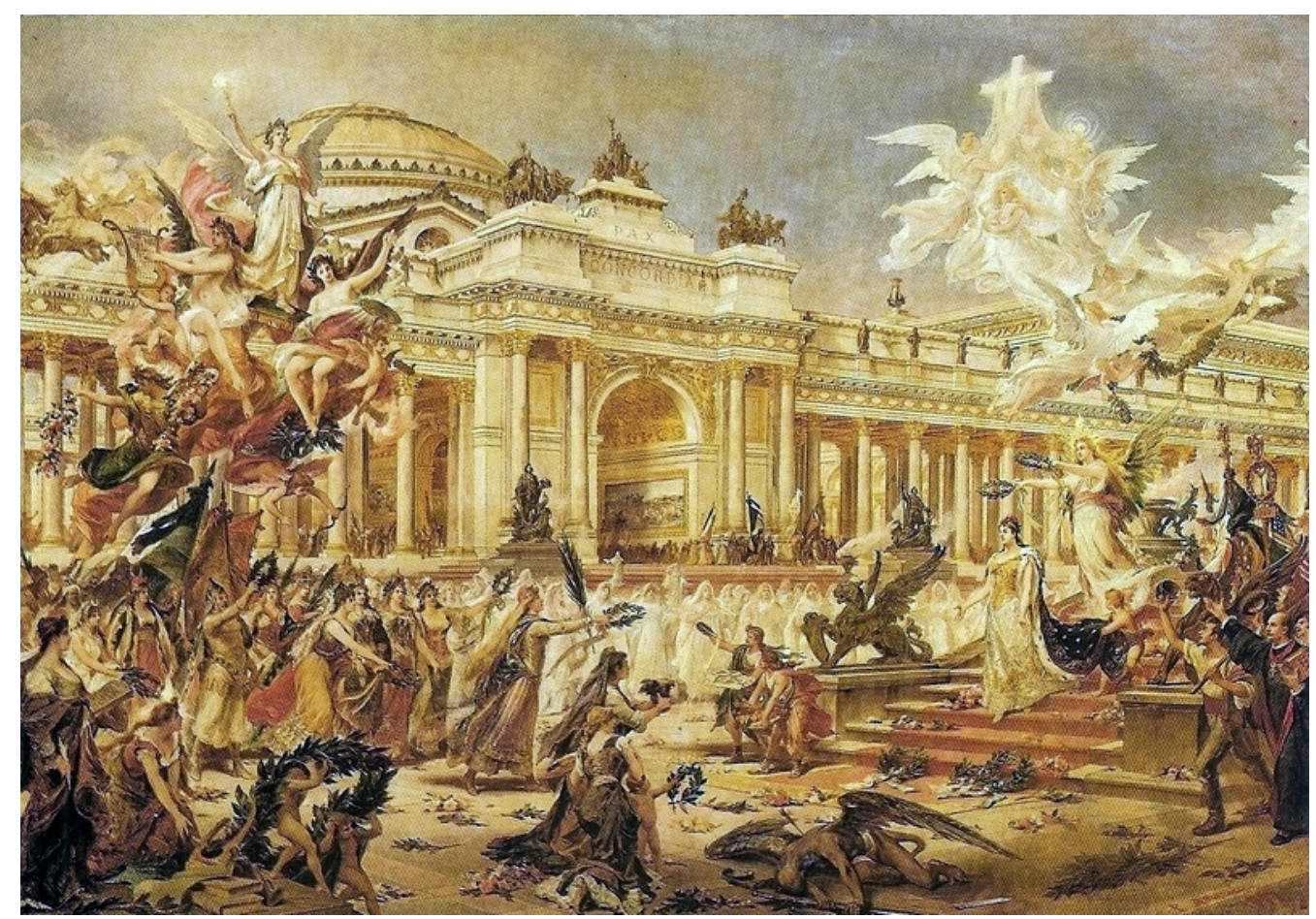

Figura 4. Paz e concórdia. Pedro Américo, 1902, óleo sobre tela, 300 x 431 cm.

Numa esplanada escalonada em frente à arquitetura clássica de um templo, em cujo pórtico se pode ler Pax et Concordia, a personificação feminina da República brasileira, descendo escalinata, é recebida por um cortejo de personificações das principais nações do mundo, entre as quais se pode identificar, pela indumentária, os Estados Unidos da América, a frente do grupo, o reino da Itália, os impérios alemão e austro-húngaro e a Grã-Bretanha. Recuado, um coro de vestais entoa cântico. Sobre a cena principal pairam dois cortejos celestiais: acima da alegoria da República, um grupo alegórico cercado de anjos representa a fé cristã e exibe vários símbolos associados ao cristianismo, como a cruz, a lâmpada, o cálice, a harpa e uma guirlanda de folhas de carvalho; acima das alegorias das nações, outro grupo alegórico representa a civilização, as ciências e as artes, que portam símbolos como um livro, tochas acesas, uma lira, um raio, coroa de folhas de carvalho e a miniatura de uma locomotiva. No canto superior, à esquerda do observador, aparece o carro de Apolo, que, diariamente, cruza os céus para trazer luz aos homens.

No primeiro plano, entre folhas de louro, guirlandas e putti, um friso de alegorias: a História, a Poesia, a Pintura, a Arquitetura, que saúdam a homenageada, e, abatido por flecha, estirado no chão, o demônio da Discórdia com sua espada quebrada. A frente da escalinata, guardada por quimeras, dois obsequiadores oferecem ao cortejo internacional vinho espumante e frutas. À direita, grupo de três homens representa o povo, que festeja a alegoria da República. Entre eles, distingue-se o barão do Rio Branco (1845-1912), com toga de magistrado, braço direito estendido na direção da homenageada, grã- 
cruz da ordem de Cristo no peito e o livro da lei junto ao coração. Em frente ao pórtico que dá acesso ao templo, duas estátuas representam Pedro Álvares Cabral (1450-1520) e Cristóvão Colombo (1451-1506), exploradores "descobridores" do "Novo Mundo". No interior do pórtico, reprodução da tela Grito do Ipiranga, do próprio artista. ${ }^{12}$

O painel decorativo é uma grande alegoria que constrói uma narrativa onde cortejos terrestres e celestiais reúnem-se para celebrar o ingresso da República brasileira na civilização e o que pode ser interpretado como o reconhecimento internacional do regime instaurado em 1889.

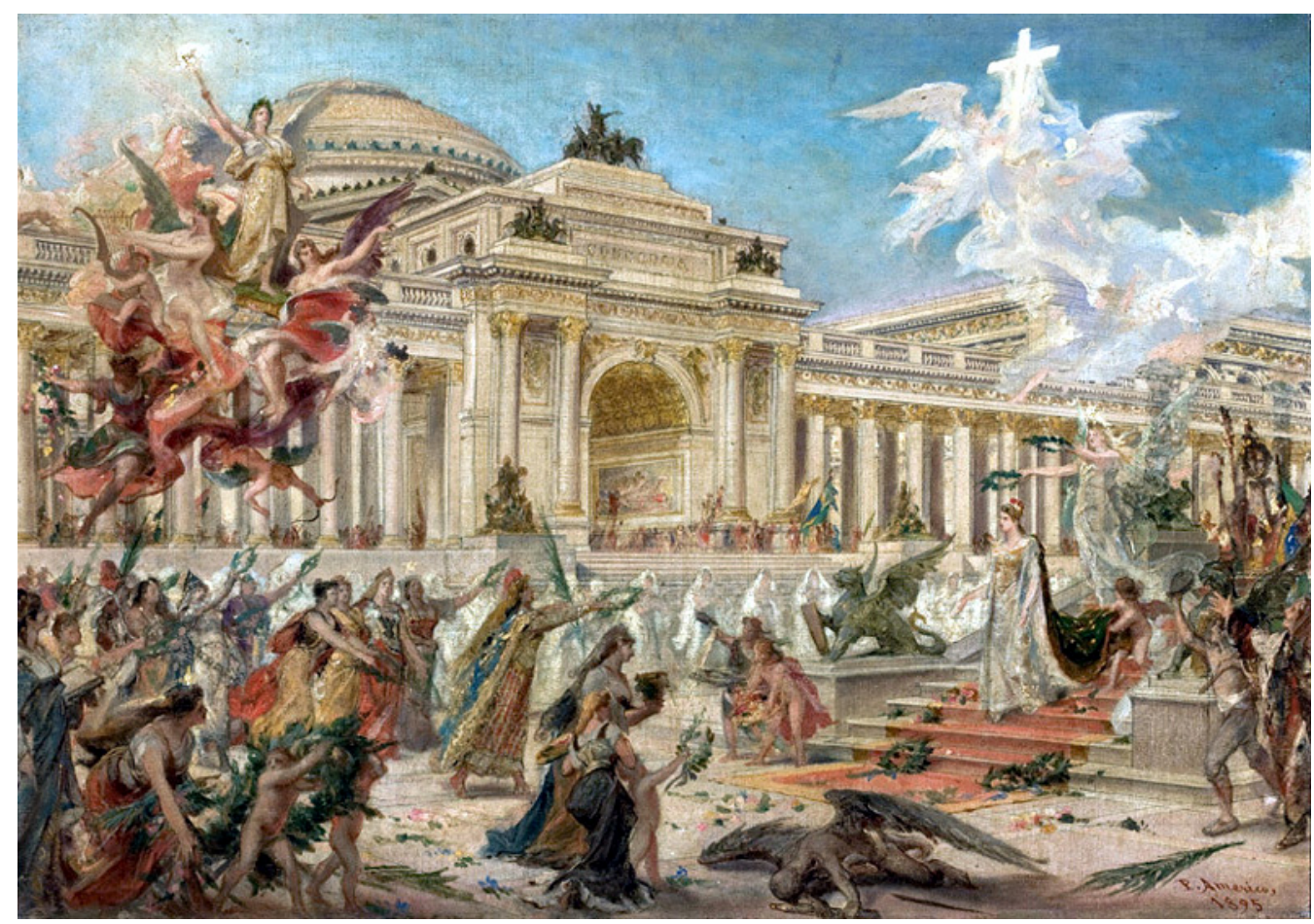

Figura 5. Paz e concórdia - estudo. Pedro Américo, 1895, óleo sobre tela, 42 x $60 \mathrm{~cm}$. São Paulo, MASP.

Um esboço da obra, de 1895, em pequenas dimensões, já revela idêntica composição, com o templo de fundo, os mesmos cortejos terrestres e celestiais, o friso de alegorias no primeiro plano, apenas com menor número de personagens. Segundo o catálogo do MASP, o estudo foi incorporado ao acervo daquele museu, em 1947, por doação de Alfredo Egydio de Souza Aranha (1894-1961), advogado e banqueiro. ${ }^{13}$ Pelas dimensões desse esboço, não se pode identificar qual a pintura reproduzida no interior do pórtico; além disso, a bandeira do Brasil é apenas esboçada na extremidade lateral à direita do

\footnotetext{
${ }_{12}$ Para descrições da alegoria de Pedro Américo, ver ROSEMBERG, Liana Ruth Bergstein. Pedro Américo e o olhar oitocentista. Rio de Janeiro: Barroso Edições, 2002, e CONDURU, Guilherme Frazão. Alegorias em confronto: os descobridores, de Belmiro de Almeida, e Paz e concórdia, de Pedro Américo: a construção danação pela pintura de história. Tese (Doutorado em Artes Visuais) - UFRJ, Rio Janeiro, 2019.

${ }_{13}$ Ver MARQUES, Luiz (coord). Catálogo do Museu de Arte de São Paulo Assis Chateaubriand: arte brasileira e outras coleções. São Paulo: Prêmio, 1998, p. 23.
} 
observador, não sendo de fácil identificação. $\mathrm{O}$ estudo pode ter chegado às mãos do doador através dos herdeiros de Pecegueiro do Amaral - colaborador do barão de Rio Branco e, como tal, intermediário na compra da obra pelo MRE, em 1903 -, que fora presenteado pelo pintor. ${ }^{14}$

$\mathrm{Na}$ biografia do artista escrita por seu genro, José Carlos Cardoso de Oliveira, publicada em 1898, a tela é mencionada, possivelmente, pela primeira vez. O biógrafo a ela se refere como "alegoria da civilização". Numa fotomontagem com a figura do artista, a pintura, ainda inconclusa, é reproduzida entre as páginas 192 e $193 .{ }^{15}$

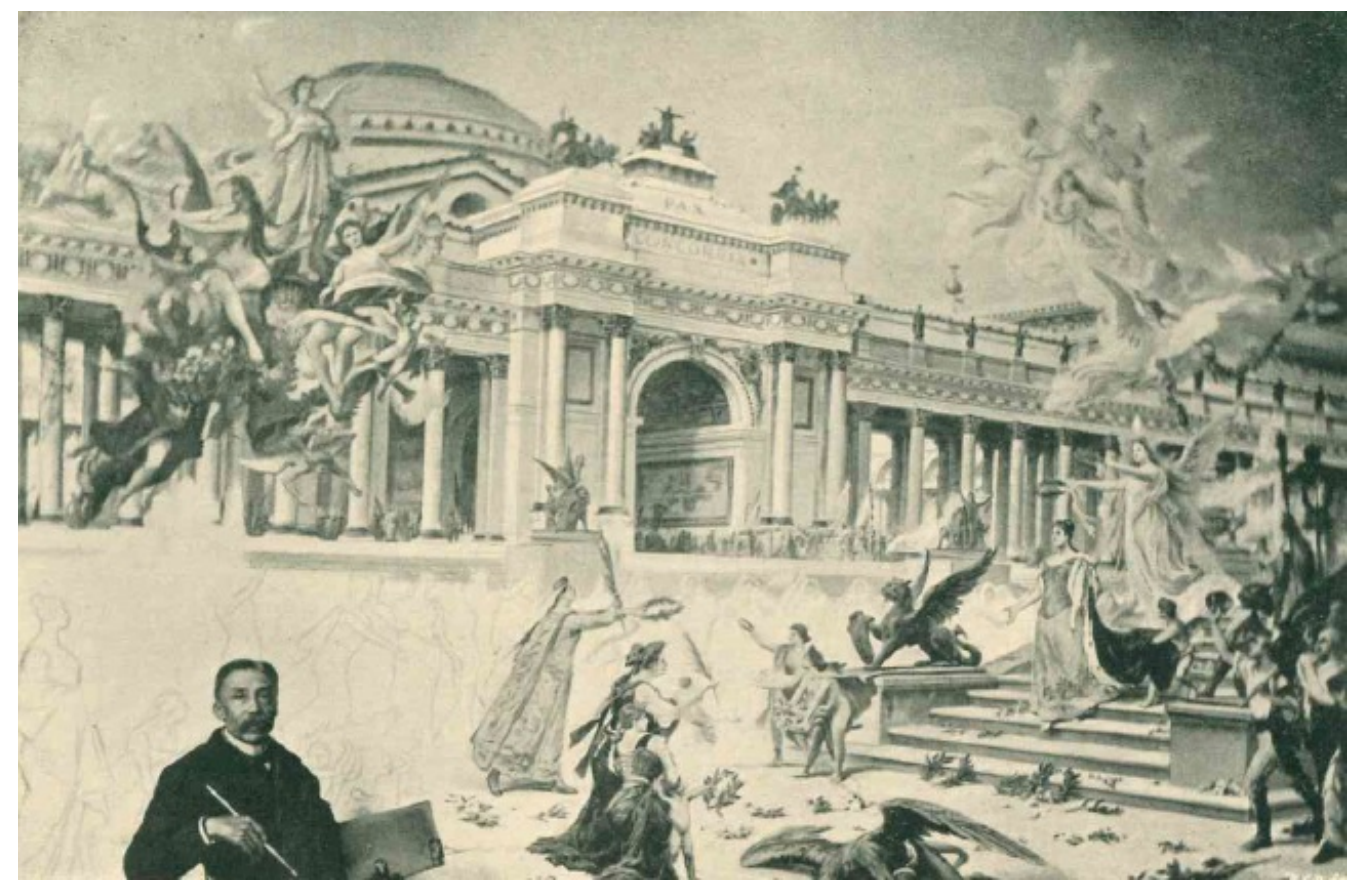

Figura 6. Pedro Américo e Paz e concórdia em execução. Fotomontagem.

A edição de abril de 1899 da Revista Moderna - revista mensal, literária e artística, editada em Paris - apresenta, com chamada na capa, reportagem sobre Pedro Américo. Assinada por Xavier de Carvalho, a matéria é um resumo da biografia de Cardoso de Oliveira, da qual reproduz seis imagens, entre elas a fotografia acima com a legenda "Pedro Américo trabalhando no seu quadro Civilização", que acreditamos ser a primeira versão da tela em ponto grande. ${ }^{16}$

Por ocasião da vista do presidente Campos Sales (1841-1913) à Buenos Aires, em outubro de 1900 - a primeira viagem oficial de um presidente da república ao exterior -, a tela foi reproduzida num dossiê especial do periódi-

\footnotetext{
14 Ver Carta de Pedro Américo para Pecegueiro do Amaral, de Florença, em 24 de novembro de 1903, Arquivo Histórico do Itamaraty, Arquivo particular do barão do Rio Branco, pasta Pedro Américo, correspondência de terceiros, lata 812, maço 4, pasta 14 (AHI 812/4/14).

${ }^{15}$ Cf. OliveIRA, J. C. Cardoso de. Pedro Américo, sua vida e suas obras: biografia documentada do ilustre pintor e literato brasileiro. Paris: Guillard, Aillaud \& Cie, 1898.

${ }^{16}$ Cf. CARVALHO, Xavier de. Pedro Américo. Revista Moderna, n. 30, ano III, Paris, abr. 1899, p. 232-237.
} 
co argentino Cara y Caretas, na página central. Há diferenças entre essa versão e a versão pertencente ao MRE, como veremos.

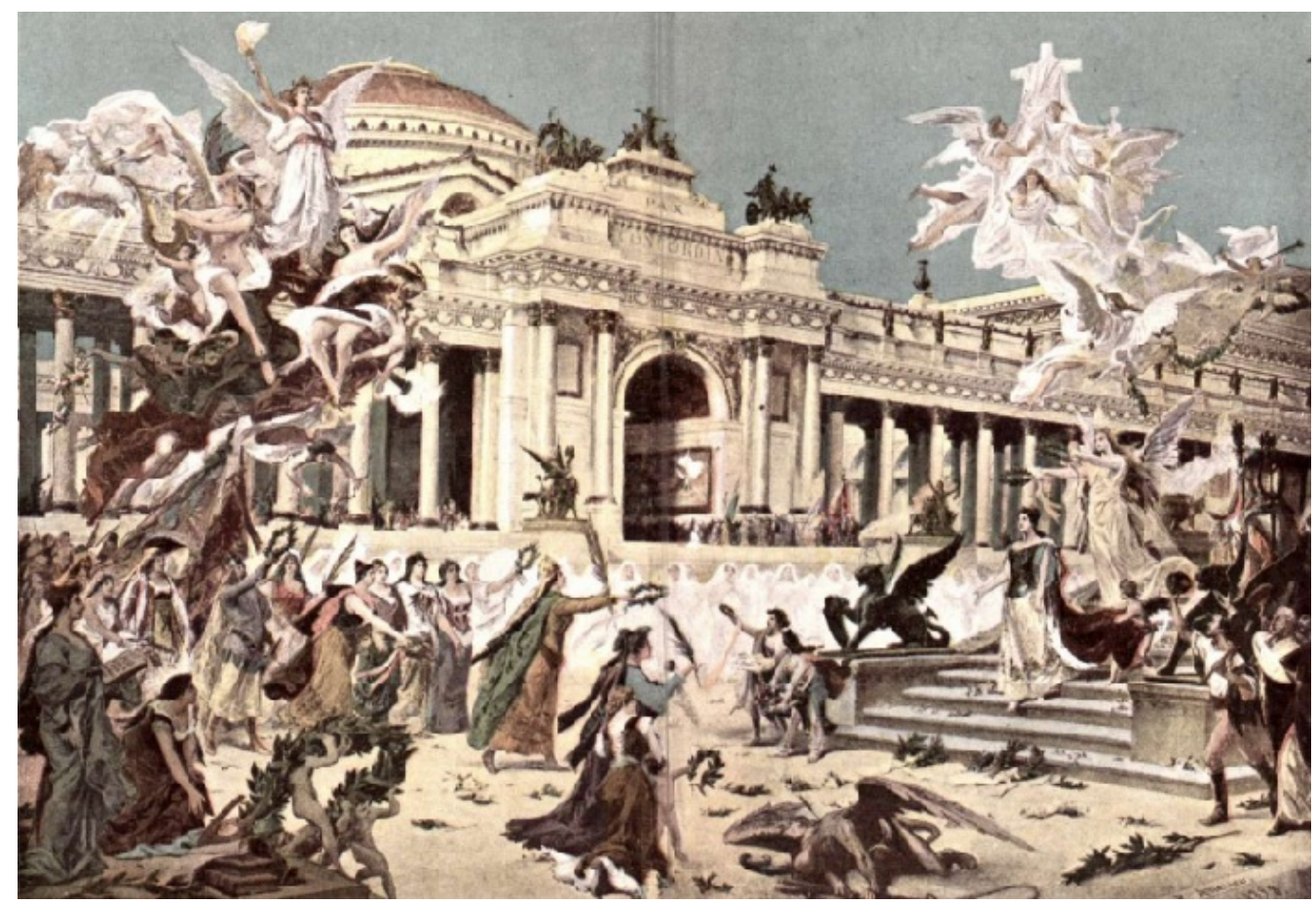

Figura 7. Paz e concórdia. Pedro Américo, $1898 .{ }^{17}$

Uma versão da obra, como alegoria da República Francesa, foi submetida, sem sucesso, ao salão decenal de belas artes, organizado durante a Exposição Universal de Paris de 1900, sob o título de Pax et Concordia - Allegorie de la France em 1900 (essai décoratif). Na ocasião, ciente de que o Brasil não se faria representar na exposição decenal por comissão nacional - ou seja, não haveria uma sessão brasileira -, o artista julgou que poderia ser aceito na seção reservada aos artistas franceses porque seu trabalho consistia numa alegoria da França. Das quatro obras que apresentou ao júri, somente foi aceita a tela Honra e pátria (Honneur et Patrie - Allégorie de l'Ordre de la Légion d'Honneur distribuant lacroix-essai décoratif). ${ }^{18}$

Com adaptações em relação à versão reproduzida em Caras y Caretas, a obra foi vendida para o MRE, em 1903, numa transação que contou com a intermediação de diplomatas amigos do pintor. ${ }^{19}$ Apresentam-se, a seguir, as diferenças encontradas entre a versão do Itamaraty e aquela de Caras y Caretas. (1) A data, no canto inferior esquerdo: enquanto na tela do MRE aparece "1902", na versão do periódico aparece "1898". (2) Ausência da figuração do

\footnotetext{
${ }^{17}$ Reproduzido de Caras y Caretas, ano III, n. 108, Buenos Aires, 27 out. 1900, p. 32, imagem da Hemeroteca Digital Hispânica da Biblioteca Nacional de Espanha. Disponível em $<$ http://hemerotecadigital.bne.es/issue.vm?id=0004104198>. Acesso em 6 jan. 2020.

${ }_{18}$ Ver Arquivos Nacionais da França, Archives Nationales F/21/4066 (fundo documental relativo à exposição de belas-artes organizada durante a Exposição Universal de 1900). O autor agradece a professora doutora Ana Maria Tavares Cavalcanti pela referência e acesso a cópias de documentos.

${ }^{19}$ Cf. AHI, 812/4/14.
} 
barão de Rio Branco, na extremidade lateral esquerda. (3) Na versão do periódico, a alegoria que lidera o cortejo de personificações de nações não veste trajes alusivos à bandeira dos EUA. (4) As estátuas que ladeiam a escadaria em frente ao pórtico não estão identificadas por inscrições. (5) A tela reproduzida no interior do pórtico não permite ser identificada como a Proclamação da independência; (6) Não há representação da bandeira nacional do Brasil na reprodução. (7) As duas figuras femininas que na versão do Itamaraty representam a Pintura e a Arquitetura, na versão anterior representam mães, acompanhadas por crianças: a figura de pé carrega uma criança, não um capitel, que exibe para a homenageada, conforme tipologia iconológica referida acima. (8) Na tela do MRE aparece a inscrição da data de 1900 no livro empunhado pela alegoria da História, que se refere ao laudo arbitral de Berna, pelo qual o governo da Suíça, árbitro escolhido pelas partes, reconheceu os direitos do Brasil à soberania sobre território reivindicado pelos franceses no Amapá e no Pará. Rio Branco fora o chefe da delegação brasileira que apresentou a defesa dos direitos ao governo suíço.

Pela data, acreditamos que a imagem do periódico reproduz o estado da pintura tal como foi submetida aos organizadores da exposição decenal de belas artes organizada no âmbito da Exposição Universal de 1900, em Paris. Não foi possível identificar de onde os editores de Caras y Caretas obtiveram a reprodução fotográfica da alegoria de Pedro Américo.

Das oito diferenças apontadas acima entre as duas versões conhecidas da tela, cinco se relacionam diretamente com a caracterização de conteúdo brasileiro: a presença de Rio Branco, a bandeira nacional, a identificação das estátuas de Cabral e Colombo, a reprodução da Proclamação da independência e a data do laudo de Berna. Essas adaptações em relação à versão submetida ao júri francês - que poderiam passar despercebidas mesmo para um olhar atento - tinham por objetivo conferir um sentido nacional brasileiro à tela. Não se sabe se a ideia de representar Rio Branco foi do artista ou se foi sugerida pelo genro e diplomata ou se atendeu à solicitação do próprio ministro. Em termos formais, as intervenções podem ser consideradas detalhes incidentais no conjunto da composição. Como se procurou demonstrar, a trajetória da alegoriaexaltação antes da aquisição pelo MRE expõe seu caráter de coringa, prestando-se a ressignificações.

\section{Análise iconológica comparada}

Como pinturas alegóricas, o pano de boca e Paz e concórdia utilizam códigos da linguagem alegórica para representar conceitos. Ambas as obras têm como protagonista a personificação do Estado; ambas reproduzem o recurso, de origem romana, à figura feminina como personificação da autoridade. Ao contrário da personificação do Império, a da República não poderia ostentar atributos como o trono, a coroa ou o cetro; as vestes à antiga e um manto, porém, são peças comuns às duas alegorias. O manto da República traz um detalhe característico do poder dinástico: o forro em arminho, que simbolizava alta dignidade, preeminência, pureza, honra e autoridade. ${ }^{20} \mathrm{~A}$

${ }^{20}$ Ver RAPELLI, Paola. Grandes dinastias y símbolos del poder. Barcelona: Electa, 2005. 
coroa sobre a personificação do governo imperial dá lugar, na cabeça da alegoria da República, a discreto barrete vermelho. Pedro Américo reproduz na personificação da República esse atributo de origem antiga, oficializado na França, que simboliza a liberdade e a adesão ao regime republicano.

A composição do pano de boca é mais simples do que a do triunfo da República. A obra de Debret registra um juramento; a cena é estática. Há mais movimento em Paz e concórdia: a personificação do Brasil republicano caminha para receber as homenagens de um grupo de nações que vem em cortejo ao seu encontro. Com a Libertação dos escravos, obra de temática nacionalista na modalidade alegórica, Pedro Américo esteve mais próximo do modelo simétrico utilizado por Debret no pano de boca do que com a composição de Paze concórdia.

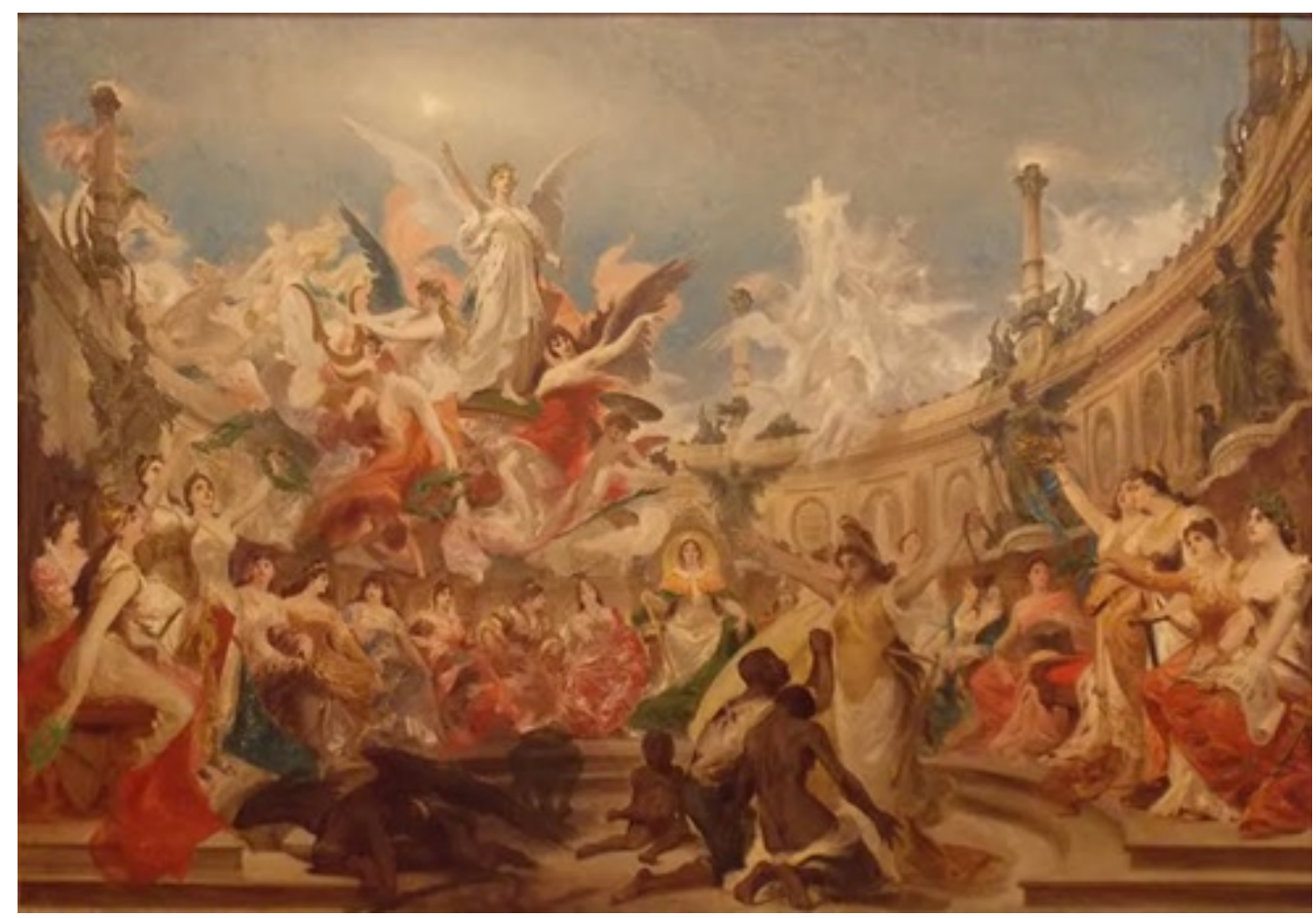

Figura 8. Libertação dos escravos. Pedro Américo, 1889, óleo sobre tela, 138 x $199 \mathrm{~cm}$. São Paulo, Pinacoteca do Estado.

Enquanto no pano de boca estão representadas províncias do Império, etnias e segmentos sociais da nação projetada, na tela do Itamaraty, Pedro Américo personifica as artes, as ciências, a religião cristã e as principais nações do mundo. Nesse sentido, a obra do francês tem um caráter mais local, enquanto a do paraibano tem pretensões universais. A representação alegórica do povo preenche o pano de boca com dezesseis figuras e outros tantos vultos em torno da personificação do Império. Paz e concórdia, ao contrário, apresenta apenas três figuras como alegoria do povo brasileiro. À diferença de Debret, que incluiu militares e civis, crianças, jovens e velhos, famílias, negros e índios, colonos brancos de duas capitanias, Pedro Américo não se preocupou com uma representação social, etária, étnica ou geográfica. 
Nas duas alegorias observam-se, portanto, modos distintos de representação do povo e do popular. A preocupação mais evidente do pano de boca é a de expressar a adesão do "povo" ao novo governo; por essa razão, na sua representação do "povo", Debret levou em conta algum grau de diversidade. Pedro Américo, ao contrário, não se preocupou com a representação da diversidade social. A aceitação do Brasil pelas nações civilizadas ou o ingresso do Brasil na civilização é seu assunto principal.

Em ambas as alegorias há referência direta ao Direito. A personificação do Império traz a constituição, que exibe e, ao mesmo tempo, protege. Embora no momento da realização do pano de boca ainda não vigorasse no Brasil uma constituição, a adoção de um texto constitucional estava no centro do debate político contemporâneo. Na tela de Pedro Américo o barão do Rio Branco traz o livro da lei junto ao coração, simbolizando o respeito aos acordos internacionais assumidos pelo país.

As respectivas referências a uma constituição, de um lado, e ao primado da lei, de outro, revelam uma diferença básica entre as duas telas quanto ao tratamento dado ao tema da representação do Estado. Enquanto o pano de boca de Debret representa uma demonstração de lealdade da população brasileira ao governo imperial e constitucional, Paz e concórdia representa a aceitação da República entre as principais nações do mundo. Debret tratou da legitimação interna da nova soberania, um assunto de política interna; Pedro Américo apresentou um assunto de política externa: o reconhecimento internacional da República.

Em relação a duas temáticas coadjuvantes na representação do poder político - a militar e a religiosa -, as respectivas posturas de cada uma das alegorias diferem de forma radical. Debret faz muito presente o elemento militar no pano de boca: o artilheiro que dispara o canhão, o pai negro fardado que oferece seu filho ao Império, os chefes indígenas de cocar e em posição de deferência, os soldados, um fuzil levado a tiracolo por um adolescente, além do fuzil no ombro da "Marianne negra".

A conjuntura da aclamação e da coroação de Pedro I foi marcada pela instabilidade política e o medo de um levante popular estava presente nos cálculos dos dirigentes. Para fortalecer a autoridade e, assim, garantir a institucionalidade era importante inculcar valores patrióticos e fomentar o sentimento de pertença à nova entidade política. Neste sentido, esperava-se do pano de boca cumprir a função de referência visual de adesão a valores nacionais.

A primeira década republicana foi conturbada, com guerras civis e crise financeira. Quando Pedro Américo assinou Paz e concórdia, em 1902, a República estava consolidada e entrara numa fase de estabilidade. Na tela o artista representou a alegoria da República, mas os signos de identidade nacional brasileira, embora explícitos, são detalhes no conjunto da composição. Não há referência à dimensão militar ou à necessidade de defesa da soberania.

Quanto a imagens ou símbolos de cunho religioso, no pano de boca nota-se apenas o terço no peito do paulista. Não fosse esse detalhe, se poderia falar na ausência da religião entre as referências de Debret. Diferença marcante com Paz e concórdia, onde Pedro Américo posiciona no ar um grupo alegórico celestial, que representa valores do cristianismo. 
Tanto Debret como Pedro Américo recorrem à arquitetura para montar seus respectivos cenários. A cena do pano de boca é representada sob uma tenda com duas cariátides, que constituem os elementos arquitetônicos visíveis, as quais suportam uma arquitrave e uma tapeçaria como cobertura. A cena da homenagem à República transcorre num grande cenário, que remete às reconstruções de Giovanni Battista Piranesi (1720-1778): uma esplanada com escadas e diferentes planos e um grande templo ao fundo.

As duas obras anunciam tempos novos, mas as respectivas posturas em relação ao passado são distintas. Ainda que Debret refira-se ao pano de boca como uma obra de "história nacional", no sentido de ser uma pintura histórica na modalidade alegórica ${ }^{21}$, a tela reproduzida como gravura não representa uma cena que tenha, de fato, ocorrido. Não há, portanto, a preocupação de descrever um acontecimento histórico, a narrativa é exclusivamente alegórica, o que, no entanto, não dispensou a preocupação do artista com a verossimilhança, que se pode perceber na caracterização dos personagens, como o paulista, o mineiro ou a família negra.

Paz e concórdia tampouco representa um acontecimento histórico e também projeta um novo tempo: o Brasil República, que ingressava na civilização. À diferença de Debret, porém, Pedro Américo faz referências ao passado, mesmo que discretas e submetidas à complexidade do conjunto. A representação de um coro de vestais, sacerdotisas romanas, simboliza o culto à pátria; as estátuas de Colombo e de Cabral aludem aos "descobrimentos" europeus; a reprodução do Grito do Ipiranga remete ao surgimento do Estado independente; e a data de 1900 refere-se à vitória diplomática do Brasil no contencioso territorial com a França.

Enquanto o pano de boca foi encomendado pelo governo imperial ao diretor do teatro, a tela de Pedro Américo foi comprada pelo MRE. É plausível supor que a encomenda não tenha sido feita diretamente a Debret, mas ao diretor, patrão do artista. Pedro Américo, depois de tentar sem sucesso expor Paz e concórdia na Exposição Universal de Paris, de 1900, logrou negociá-la com o barão do Rio Branco, ministro das relações exteriores, e, assim, colocar mais uma de suas obras em prédio público. A obra de Debret oferece, enfim, mais elementos identificáveis como brasileiros do que a tela coringa de Pedro Américo.

Artigo recebido em 7 de março de 2020. Aprovado em 22 de abril de 2020.

${ }^{21}$ Cf. DEBRET, Jean-Baptiste, op. cit., p. 559. 